УДК 316.3

DOI 10.18522/2227-8656.2020.3.11

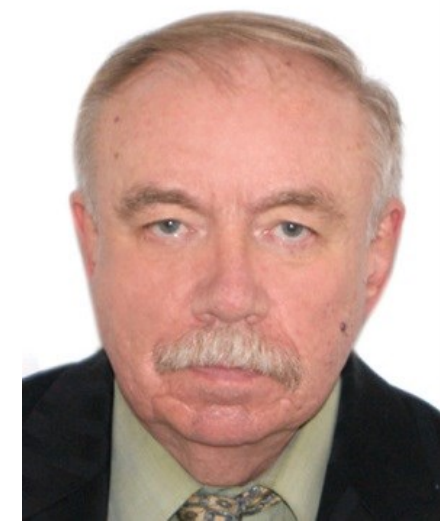

НАЦИЯ В АНАЛИТИЧЕСКОМ ФОКУСЕ: НЕКОТОРЫЕ АСПЕКТЫ ЗАРУБЕЖНЫХ И РОССИЙСКИХ ИССЛЕДОВАНИЙ ${ }^{1}$

\author{
Авксентьев Виктор Анатольевич \\ Доктор философских наук, \\ профессор, \\ главный научный сотрудник, \\ Федеральный исследовательский центр \\ «Южный научный центр РАН», \\ г. Ростов-на-Дону, Россия, \\ e-mail: avksentievv@rambler.ru
}

\author{
Аксюмов Борис Владимирович \\ Доктор философских наук, доцент, \\ профессор, кафедра социальной философии \\ и этнологии, \\ Гуманитарный институт, \\ Северо-Кавказский федеральный университет, \\ г. Ставрополь, Россия, \\ e-mail: aksbor@mail.ru
}

Актуальность исследования определяется незавершенностью процессов нациестроительства в современной России, наличием конкурирующих проектов, отсутствием консенсуса

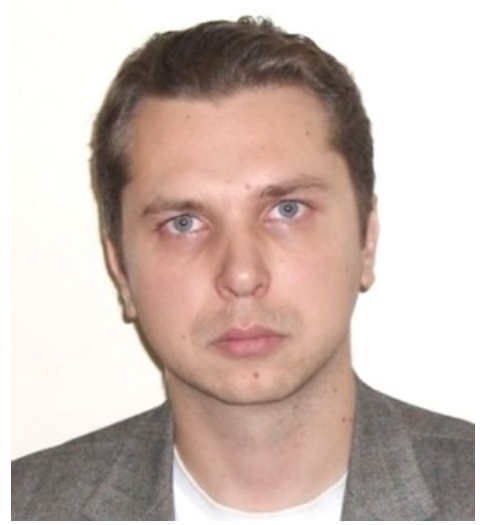

\section{NATION IN ANALYTICAL FOCUS: SOME ASPECTS OF FOREIGN AND RUSSIAN STUDIES}

Viktor A. Avksentev Doctor of Philosophical Sciences, Professor, Chief Researcher, Federal Research Centre "The Southern Scientific Centre of The Russian Academy of Sciences", Rostov-on-Don, Russia, e-mail: avksentievv@rambler.ru

\author{
Boris V. Aksiumov \\ Doctor of Philosophical Sciences, \\ Associate Professor, Professor, \\ Department of Social Philosophy and Ethnology, \\ Humanitarian Institute, \\ North Caucasus Federal University, \\ Stavropol, Russia, \\ e-mail: aksbor@mail.ru
}

The relevance of the study is determined by the incompleteness of nation-building in modern Russia, the presence of competing projects, the lack of consensus in the scientific community

${ }^{1}$ Публикация подготовлена в рамках научного проекта «Тенденции этнизации / деэтнизации общественно-политической жизни на Северном Кавказе», грант РФФИ № 20-011-00132. 
в научном сообществе и терминологическими разночтениями в политических документах. Целью статьи являются выяснение научного статуса категории «нация» и определение причин перехода проблемы нации в разряд нерешаемых. Анализируется эволюция представлений о нации в зарубежной научной литературе - от примордиализма через социальный конструктивизм к эпистемологическому постмодернизму. Показана асинхронность развития концепта нации в зарубежной и российской литературе, что определяется не отставанием российской науки, а отличными от зарубежной науки философско-мировоззренческими установками. В зарубежной, прежде всего англоязычной, литературе изучение феномена нации происходит в контексте меняющихся теоретикометодологических установок: от научного реализма, гносеологического оптимизма и социального материализма, утверждающих «вечность» национальных форм жизни, через социальный конструктивизм, признающий объективный, но конструируемый характер национальных общностей, до эпистемологического постмодернизма, лишающего нацию объективных оснований. Вписанность проблемы нации в доминирующие эпистемологические и социально-философские концепции привела к тому, что сама проблема на этапе перехода от социального конструктивизма к эпистемологическому постмодернизму приобрела статус философской, вечной и нерешаемой, и ее обсуждение фактически зашло в тупик. В российской науке в настоящее время происходит движение от примордиализма к конструктивизму. Спецификой российского дискурса о нации является вписанность не столько в философскоэпистемологическую картину мира, сколько в политический контекст. Делается вывод, что активно продвигаемый в настоящее время концепт российской нации может выступить теоретической основой интеграции российского общества не в силу теоретических преимуществ, а в силу того, что является наиболее удачным конструктом для решения проблем пространственно-территориального и этнокультурного развития России. and terminological differences in political documents. The purpose of the article is to clarify the scientific status of the term "nation" and determine the reasons for the transition of the problem of nation to the category of unsolvable. The evolution of ideas of the nation from primordialism through social constructivism to epistemological postmodernism is analyzed in foreign scholarly literature. The asynchrony of the development of the concept of nation in foreign and Russian literature is shown, which is determined not by the "lag" of Russian science, but by philosophical and world outlooks that are different in Russian and foreign science. In foreign, primarily English-language literature, the study of the phenomenon of a nation takes place in the context of changing theoretical and methodological attitudes: from scientific realism, epistemological optimism and social materialism, affirming the "eternity" of national life forms, through social constructivism, which recognizes the objective but constructed nature of national communities, to epistemological postmodernism, depriving the nation of objective foundations. The inscription of the problem of nation into the dominant epistemological and socio-philosophical concepts led to the fact that the problem itself at the stage of transition from social constructivism to epistemological postmodernism acquired the status of a philosophical, "eternal" and unsolvable one and its discussion virtually reached a deadlock. In Russian science, there is currently a movement from primordialism to constructivism. The specificity of the Russian discourse on the nation is its "inscription" not so much into the philosophical and epistemological picture of the world as into the political context. It is concluded that the currently actively promoted concept of the Russian nation can serve as the theoretical basis for the integration of Russian society not due to theoretical advantages, but because it is the most appropriate construct for solving the problems of spatial, territorial and ethnocultural development of Russia. 
Ключевые слова: нация; примордиализм; конструктивизм; эпистемологический постмодернизм; российская нация.
Keywords: nation; primordialism; constructivism; epistemological postmodernism; Russian nation.

\section{Введение}

Проблема нации в последние тридцать лет постоянно присутствует в российском научном и политическом дискурсе. Главным катализатором этого интереса является политическая актуальность всего комплекса вопросов, объединенных концептом нации. Дискуссии о природе нации, соотношении этнического и гражданского компонентов в формировании нации стали важным сюжетом в социальных и гуманитарных науках в России, фактически перейдя в разряд нерешаемых, вечных вопросов. Эти дискуссии имели несколько циклов - от призывов «забыть о нации» до активного продвижения в общественное сознание идеи российской нации. В выборе точки зрения отчетливо просматриваются национально-территориальные предпочтения: на федеральном уровне дискурса, формируемого московским научноэкспертным сообществом, доминирует гражданско-политическое понимание нации, в то время как в республиках превалирует этническая трактовка нации.

Отсутствие научного консенсуса манифестируется на политическом и доктринальном уровнях. В новой редакции (2018 г.) Стратегии государственной национальной политики Российской Федерации на период до 2025 года как синонимичные используются понятия «многонациональный народ Российской Федерации» и «российская нация»; в этом же документе используется концепт российской цивилизации «культурный код» (О внесении изменений в Стратегию ..., 2018). С практико-политической точки зрения такое сочетание разнородных концептов в одном документе оправдано: документ должен быть принят сторонниками различных воззрений. Важно также учесть, что документ предназначен прежде всего для управленцев различного уровня, которым необязательно быть в курсе затяжных дискуссий о природе наций. Но с теоретической точки зрения необходимо признать: российское социогуманитарное знание движется по одному и тому же кругу уже три десятилетия. В научном мире достижение консенсуса необязательно, но с учетом непосредственного входа национальной проблематики в российский политический процесс минимальное концептуальное и терминологическое согласие необходимо.

Дискуссии о нации активно продолжаются и в зарубежной научной литературе. Интерес к этой проблеме в зарубежных исследованиях 
поддерживается обширными исследованиями национализма - феномена, генетически или по крайней мере этимологически связанного с нацией.

Цель настоящей статьи - выяснить, в чем причина теоретической нерешаемости проблемы нации. Статус нерешаемых, вечных имеют философские вопросы, в других отраслях науки, в частности, в этнополитологии, проблемы должны быть решаемыми. В статье мы стремились показать, что проблема нации имеет скорее философский, чем научный (этнологический, политологический, социологический), характер, вписана в ткань современного философского дискурса, а поэтому не может иметь окончательного решения.

\section{Методология исследования}

Вдохновляющим импульсом для современной (начиная с 1960-х гг.) западной науки о нации и национализме стала критика примордиалистских подходов. Однако исследователи отмечают, что подлинные версии примордиализма чрезвычайно трудно найти в академической литературе (Coakley, 2018). Он предстает в различных вариантах наивного реализма, объективизма, гносеологического оптимизма, социального материализма.

Доминирующим методологическим принципом западной и особенно англо-американской науки о нации и этничности со второй половины прошлого столетия стал социальный конструктивизм, отвергнувший «теоретическую наивность», на которой выстроил свою концепцию примордиализм, принимая социальный мир за самоочевидную реальность. Отметим, что социальный конструктивизм затрагивает все объекты социальной реальности и является философско-гносеологической, а не этнологической концепцией. По мнению Э. Балибара, «всякая социальная общность, воспроизводимая под воздействием институтов, является воображаемой. То есть ее основа - это проекция индивидуального существования на ткань коллективного повествования, на узнавание общего имени и на традиции, переживаемые как след незапамятного прошлого (даже если они были сфабрикованы и усвоены при недавних обстоятельствах)» (Балибар, 2004. С. 111).

Важнейшей отправной точкой для развития конструктивистских представлений о нации можно считать социологию знания (П. Бергер и Т. Лукман). Неожиданно для сторонников «самоочевидной» социологии оказалось, что «для правильного понимания "реальности sui generis" общества требуется исследование того, как эта реальность конструируется» (Бергер, 1995. С. 36). Конструктивизм, усомнивший- 
ся в существовавшей на тот момент картине социального мира, открыл перед социальной наукой совершенно новые горизонты. Что такое общество? Что такое государство? Что есть нация? Эти и многие другие вопросы снова приобрели актуальность.

В области изучения наций переход от примордиализма к конструктивизму означал радикальную переработку методологического аппарата, появление новых ответов на ключевые вопросы. По утверждению Х. Сетон-Уотсона, которого Б. Андерсон назвал автором «самого лучшего и всеобъемлющего текста о национализме в англоязычной литературе», «никакого “научного определения” нации разработать нельзя; и вместе с тем, - добавляет автор, - феномен этот существовал и существует до сих пор» (Seton-Watson, 1977. Р. 5). П. Колсто справедливо отмечает, что не бывает правильного или неправильного определения: определения могут только более или менее адекватно подходить для рассматриваемой проблемы (Kolstø, 2018. P. 38).

Конструктивистов уже не устраивали казавшиеся примордиалистам очевидными признаки нации, такие как язык, территория, общность культуры и т. д., хотя некоторые из исследователей, например, Э. Геллнер, по-прежнему использовали их. Отказ, полный или частичный, от объективных признаков нации вызывал потребность в поиске других характеристик, через которые было бы возможно конституировать нацию.

Тон здесь задал Б. Андерсон, определивший нацию как «воображенное политическое сообщество» (Андерсон, 2016. С. 47). По словам С.П. Баньковской, «нация в такой трактовке выступает как новый, характерный для современного общества способ связывать воедино, в целостном восприятии, пространство, время и человеческую солидарность» (Баньковская, 2016. С. 17-18).

Несмотря на субъективность воображения, Б. Андерсон тем не менее не сомневается в онтологической реальности нации как сообщества, обладающего определенным набором ценностей, символов, традиций. Воображаемое единство нации означает ее реальное единство, так же как само объективное существование нации утверждается в актах воображения членов данной политической и культурной общности.

В конце XX в. в социально-гуманитарном знании начался переход к эпистемологическому постмодернизму, обозначенный Э. Хобсбаумом, одной ногой стоявшим еще на позициях конструктивизма. Однако его концепция изобретенных традиций вкупе с агностицизмом относительно идентификации национального сообщества максимально приближают его учение к постмодернистскому направлению. По 
утверждению Хобсбаума, «те, кто принадлежит к “нации”, утверждают, что последняя представляет собой в известном смысле важнейшую коренную предпосылку социального бытия и даже индивидуальной идентификации ее членов - при этом, однако, совершенно невозможно указать сколько-нибудь удовлетворительный критерий, который позволил бы нам определить, какие именно из многочисленных человеческих сообществ должны носить ярлык “нации”» (Хобсбаум, 1998. C. 11).

Хобсбаум еще не решается на отрицание объективного существования человеческих сообществ, в этом сохраняется его связь с конструктивизмом, однако агностицизм в идентификации социальных групп роднит его концепцию с эпистемологическим постмодернизмом. Главным на сегодняшний день представителем постмодернистского понимания нации можно считать Р. Брубейкера, утверждающего, что социальный конструктивизм себя исчерпал, стал слишком привычным, респектабельным и потому неспособным на научные прорывы. Он пишет: «И дело не в ошибочности идеи социальной конструкции, а скорее в том, что сегодня она кажется слишком уж правильной, слишком знакомой, слишком непреложной, а потому и не может породить трения, стать источником силы и новизны, без которых невозможно развивать аргументы и приходить к новым озарениям» (Брубейкер, 2012. C. 17).

В отличие от конструктивистов, Брубейкер отрицает объективную реальность социальных групп, которые существуют только как результаты категоризации социального мира. По утверждению Брубейкера, «по самой своей природе категоризация создает группы и приписывает к ним членов; но созданные таким образом группы не существуют независимо от бесчисленных актов категоризации, публичных и частных, благодаря которым они удерживаются изо дня в день» (Брубейкер, 2012. С. 153).

\section{Результаты и дискуссия}

Для примордиалистов нация (как понятие и как реальность) не представляет особых проблем: «нации», «народы» и «этносы» объявляются исходными формами социальной организации человеческих сообществ. Дефиниции нации или народов осуществляются через перечисление верифицируемых и объективных признаков. Например, еще в 1913 г. И.В. Сталин определил нацию как «исторически сложившуюся устойчивую общность людей, возникшую на базе общно- 
сти языка, территории, экономической жизни и психического склада, проявляющегося в общности культуры» (Сталин, 1934. С. 6).

Перечисленные в определении признаки достаточно легко эксплицируются, а их объективный характер не вызывает сомнений. В советской идеологии эта трактовка нации трансформировалась в ленинское определение нации, на котором выросли три поколения обществоведов и которое укоренилось в общественном сознании.

Подобное определение нации привлекает своими понятными и верифицируемыми характеристиками, не порождает онтологических или гносеологических (эпистемологических) осложнений. Это, видимо, сыграло свою роль в том, что в англоязычной версии «Википедии»источнике не научном, но важном для формирования общественных образов - дается следующее определение нации: «Нация - это устойчивое сообщество людей, сформировавшееся на основе общего языка, территории, истории, этничности или психологического склада, проявляющегося в общей культуре». Правда, далее делается оговорка, что «нация более отчетливо политическая, чем этническая группа» (Nation). Примечательно, что в статье «Википедии» не упоминаются ни Сталин, ни Ленин, ни советская трактовка нации, а библиографический аппарат полностью представлен зарубежными, в основном англоязычными авторами.

Основные дискуссии в примордиалистских трактовках нации развернулись вокруг перечня признаков нации. По мнению конструктивистов, бесконечные дискуссии о признаках нации - плата за попытку более научного анализа этого феномена. Путь решения этой проблемы - отказ от овеществления социальных феноменов и поиск более или менее надежных источников социального знания в субъективных восприятиях реальности, например в форме того же воображения. В итоге «объективное» существование нации становится фактом субъективной реальности, напрямую зависящим от актов самосознания и воображения. Иными словами, «объективное» существование нации поддерживается за счет субъективной веры или убежденности в том, что эта нация на самом деле существует, причем существует в самом что ни на есть примордиалистском фрейме, т. е. как социальная вещь.

По меткому замечанию С.В. Соколовского, «независимо от того, существует ли (при любых трактовках и критериях существования) конкретная нация как самостоятельное политическое сообщество, сами воображение и убежденность носителей идеологии национализма в существовании этой нации оказываются достаточными, чтобы заставить их действовать, как если бы она безусловно существовала, вплоть 
до принесения жизни в жертву во имя этой нации» (Соколовский, 2016. С. 42). В этом смысле можно утверждать, что социальный конструктивизм стремится к той же цели, что и примордиализм, - обосновать реальное и объективное существование нации, но иными средствами. Более того, он укрепляет идею нации, связывая ее с идентичностью и самосознанием. Неслучайно сторонники социального конструктивизма часто вспоминают известное изречение Э. Ренана о том, что нации - это ежедневный плебисцит. Также уместно вспомнить утверждение Э. Геллнера, что «два человека принадлежат к одной нации лишь только в том случае, если они признают принадлежность друг друга к этой нации. Иными словами, нации делает человек, нации это продукт человеческих убеждений, пристрастий и наклонностей» (Геллнер, 1991. С. 35).

И все же метод конструирования нации посредством субъективных категорий вызывает ряд вопросов. Термин «воображение» не только субъективен, но и весьма неоднозначен. Как справедливо отмечает Э. Смит, анализируя концепцию Б. Андерсона, «термины вроде "изобретения" и "воображения" могут означать различные вещи и обычно используются именно в тех смыслах, от которых Андерсон стремится дистанцироваться: очень легко перейти от "воображаемого" в смысле “вымышленного" к “воображаемому” в смысле “иллюзорного” или “сфабрикованного”...» (Смит, 2004. С. 255).

Действительно, конструктивистские способы понимания нации, редуцируя бытие нации к субъективному мировосприятию, неизбежно сталкиваются с серьезными, философскими по своему характеру затруднениями. Является ли субъективная убежденность в существовании нации залогом ее объективной реальности? Что такое социальная реальность и может ли подобная реальность в принципе существовать, если она в конечном итоге все равно просвечивается сквозь призму человеческой субъективности? В любом случае вопрос об объективном существовании наций, классов, этносов и других подобных социальных общностей остается неразрешимым в своем принципиальном философском звучании, поэтому дело гносеологического выбора - признавать их объективное существование или сомневаться в нем.

Однако какие именно сообщества мы можем обозначить в качестве наций? Этот вопрос имеет для конструктивизма важное значение не только потому, что появляется потребность дифференцировать нацию от других подобных сообществ (например, от этноса), но и потому, что сообщество, точнее, люди, из которых оно состоит, становится для многих конструктивистов источником формирования наций, 
единственным способом доказательства их реального существования. В этом отношении определение сообщества, именующего себя и именуемого другими в качестве нации, приобретает ключевое значение. Помимо всего прочего, именно в этом пункте происходит концептуальный переход от классического социального конструктивизма с его уверенностью в объективном существовании наций к тому направлению, которое можно обозначить как эпистемологический постмодернизм. Такое название оправдывается тем обстоятельством, что в рамках данной традиции (а она уже сложилась) нации, как и многие другие социальные общности, основанные на групповой идентичности, предстают либо в виде простых символов (Вердери, 2002. С. 299), либо как дискурсивные формации (Калхун, 2006), либо, наконец, как чисто эпистемологические реальности.

Конструктивизм отправляется в научное исследование с целью обнаружить в совокупности объективно существующих человеческих сообществ те группы, которые можно было бы обозначить в качестве национальных. На главный онтологический вопрос - существуют ли социальные общности (группы), которые в анализе обозначаются нами в качестве наций, - социальный конструктивизм дает однозначно утвердительный ответ.

По мнению же Р. Брубейкера и его единомышленников, социальные группы возникают только как результат категоризации и классификации и не существуют независимо от них. Можно согласиться с тем, что конкретные названия групп и приписываемые им характеристики являются неким итогом научных штудий, а также с тем, что выбираемые нами термины, набор определенных признаков условны и зависят от политических, культурных и интеллектуальных особенностей эпохи, предпочтений отдельных мыслителей и даже разного рода случайностей. Однако трудно согласиться с этим полным и безоговорочным отрицанием объективного существования социальных групп, хотя сам Р. Брубейкер постоянно подчеркивает, что подобное отрицание почти никак не влияет на сам процесс научного познания и тем более на реальную социальную жизнь, которую мы не в состоянии ни представить, ни описать без привычных групповых категорий. Исследование нации превращается у Р. Брубейкера в «разговор о нации», который вполне «может обходиться без утверждения о существовании “наций”» (Брубейкер, 2012. С. 71).

Эпистемологические (гносеологические) и онтологические рассуждения Р. Брубейкера отчасти напоминают даже некоторые тезисы солипсизма Дж. Беркли, например, о том, что быть - значит быть вос- 
принимаемым. Нам более близка позиция Э. Смита, которого некоторые ученые несправедливо иногда называют примордиалистом. Критикуя рассуждения Р. Брубейкера об эпистемологической природе наций, он пишет: «Мы в состоянии, я полагаю, избежать социального овеществления, сохранив при этом представление о нациях как о реальных сообществах (необязательно “устойчивых" и, конечно же, не “неизменных и данных" или “внутренне однородных”); и мы должны сделать это, поскольку “нация", не будучи только лишь категорией практики, институционализированной формой и случайным событием, как справедливо замечает Брубейкер, также связана с живым и осязаемым сообществом, что приводит к совершенно реальным и серьезным последствиям. Именно социальная реальность таких последствий заставляет исследователей считать нации реальными сообществами, существующими наряду с другими видами живых и осязаемых сообществ» (Смит, 2004. С. 151).

На сегодняшний день западная наука о нации по большому счету топчется на месте. Ставшие уже классическими труды Э. Кедури, Б. Андерсона, Э. Геллнера, Э.Д. Смита, Э. Хобсбаума остаются непревзойденной вершиной и служат главным источником для теоретических выводов новых поколений исследователей. Никто уже не притязает сегодня на создание крупных теоретических работ о нации и национализме, основной вектор исследовательских усилий - case study.

Несколько иной тренд характерен для отечественной традиции изучения нации, которая изначально оформилась как примордиалистская. Германская, т. е. этническая, концепция нации, воспринятая социал-демократией Австро-Венгрии и унаследованная Лениным и Сталиным, оказала решающее воздействие на изучение проблематики в советский период. Поэтому неудивительно, что советская этнология занимала последовательно примордиалистские позиции, овеществляя этничность и придавая ей ключевое значение в динамике социальных процессов.

Нациестроительство в СССР было осуществлено на основе германской концепции нации, и другой вариант вряд ли был возможен. Можно полностью в данном случае согласиться с Р. Брубейкером, который утверждает, что «советский режим раскроил советскую территорию более чем на пятьдесят якобы автономных национальных "родин”, каждая из которых “принадлежала" конкретной этнонациональной группе; и он наделял каждого гражданина этнической "национальностью”, которая приписывалась ему при рождении на основании происхождения, регистрировалась в личных идентификационных до- 
кументах, фиксировалась в бюрократических реестрах и использовалась в целях контроля над доступом к высшему образованию и рабочим местам. Тем самым, - заключает автор, - режим не просто признавал или ратифицировал уже существующее положение дел; он вновь создавал и лица, и места как национальные» (Брубейкер, 2012. С. 109-110).

Советские политики и ученые постоянно подчеркивали стратегическую значимость этнополитической формулы «один народ - много наций». Концепт советского народа как новой исторической общности людей придавал всей конструкции мощный позитивный окрас. Отвечая на призывы некоторых исследователей скорректировать дискурс и реальные векторы советской этнополитики в сторону построения единой советской нации, идейный лидер советской этнологической школы Ю.В. Бромлей писал: «Для возражений есть тем большие основания, что подобная характеристика советского народа означала бы косвенное отрицание реального факта существования наций в составе Coветского государства» (Бромлей, 1983. С. 373).

Советский Союз, развалившийся, как это обычно происходит с этнофедерациями, в соответствии с границами между республиками, оставил в наследство современной России практически ту же самую конструкцию, закрепленную в начальной фразе российской Конституции: «Мы, многонациональный народ Российской Федерации...». Согласно документу, именно многонациональный народ является «носителем суверенитета и единственным источником власти». По мнению К.С. Гаджиева, «данное определение представляется спорным (если не ошибочным), поскольку в действительности в современной науке и реальной жизни речь идет не о народном, а о национальном государстве, и соответственно, следует говорить не о "многонациональном народе”, а о единой российской “полиэтнической нации”» (Гаджиев, 2018. С. 131).

Может создаться впечатление, что здесь мы имеем дело не более чем со спором о терминах. На самом деле этот спор отражает глубинную конкуренцию двух проектов современного российского нациестроительства - этнического и гражданского. Советская и даже еще более ранняя традиция отождествления национального с этническим укоренилась в отечественной культуре, однако проблема в том, что эта традиция в российских республиках только укрепляется, и мы имеем дело с сильным лоббированием идеи этнонации со стороны ученых из республик, политиков, деятелей культуры.

Конструкция «один народ - много наций», помимо печального в этом смысле советского опыта, представляется рискованной по двум 
причинам. Во-первых, данная конструкция предполагает масштабную этнизацию социально-политических, культурных и иных процессов в федеральном и региональном формате. Развитие этнонаций требует, как это было со многими советскими республиками, серьезных инвестиций в национальное (этническое) развитие, что неизбежно влечет за собой укрепление этнической идентичности, которая, как мы полагаем, вступает в прямую конкуренцию с гражданской идентичностью (Авксентьев, 2010). Во-вторых, существование этнонаций, бытие которых фиксируется в самосознании референтных этнических групп, скрывает в себе серьезные политические риски, особенно опасные для сложных в этнокультурном плане государств. Как утверждает один из известных теоретиков национализма Дж. Бройи, «нация должна иметь политическую автономию, лучше всего - в форме суверенного государства» (Бройи, 2002. С. 204).

Современная российская этнополитика ориентирована на укрепление гражданских траекторий нациестроительства и деполитизацию этничности, что предполагает более надежную и устойчивую конструкцию - «одна нация - много народов (этносов)». Модель российской гражданской нации, предлагаемая многими исследователями (Дробижева, 2015; Клименко, 2015; Паин, 2017; Семененко, 2015), решает (по крайней мере, в теории) обе главные задачи государственной национальной политики - укрепление гражданской идентичности и сохранение этнокультурного разнообразия. Этнический компонент строительства российской нации важен и необходим, но не как фактор построения региональных этнонаций, а как условие культурного развития российских этносов. Исследователи также предлагают снять противоречие между этнической и гражданской идентичностями посредством формирования национально-цивилизационной идентичности (Лубский, 2016).

Интересная попытка примирить и гармонизировать этнические и гражданские трактовки нации предпринята в концепции «нации наций», принадлежащей В.А. Тишкову. Важно отметить, что именно этот ученый стоит у истоков отечественного социального конструктивизма. Вариант российского конструктивизма, наиболее полно представленный в творчестве В.А. Тишкова, можно обозначить как умеренный, сдерживаемый, с одной стороны, глубокими традициями отечественного примордиализма, а с другой - критическим восприятием идей западного конструктивизма и тем более постмодернизма. В.А. Тишков соглашается с выводами многих западных конструктивистов о решающем значении идентичности в утверждении нации как 
состоявшейся и объективно существующей социальной общности. Однако, в отличие от некоторых из них, гораздо большее внимание он уделяет объективным границам и условиям конструирования современной нации, что в большей степени роднит его взгляды с воззрениями Э. Смита, а не, к примеру, Э. Хобсбаума. Границы социального конструирования, заданные существующими культурными, политическими и иными традициями, направляют вектор социального воображения, в том числе воображения нации как именно такого, а не иного сообщества, обладающего идентичностью, соответствующей тому материалу, на основе которого она была отчасти сконструирована, а отчасти сформировалась сама. По определению В.А. Тишкова, «нация это воображаемая общность, социальный конструкт, политическая метафора, обладающая мобилизующей силой и имеющая почти всеобщее распространение. Тем самым эта категория политики и идеологического дискурса становится реальностью в силу своего воздействия на сознание и поведение людей. Нация - это форма коллективного самосознания (идентичности) людей по поводу принадлежности к определенной общности, которую они считают нацией» (Тишков, 2016. С. 9).

Итак, именно идентичность, т. е. восприятие или воображение себя как части социальной общности под названием «нация», является главным и важнейшим нациеобразующим признаком с точки зрения социального конструктивизма. При всей значимости объективных признаков (территория, институты, структуры) именно субъективная идентичность, тот самый «ежедневный плебисцит», окончательно легитимирует нацию и придает ей мощное аксиологическое звучание, заставляющее человека при определенных условиях жертвовать собой во имя этой «абстракции».

\section{Выводы}

Дискурсы о нации в зарубежной и отечественной науке имеют определенную асинхронность. В современной западной науке вектор дискурса направлен от конструктивизма к эпистемологическому постмодернизму, в отечественной - от примордиализма к конструктивизму. Однако эту асинхронность нельзя назвать отставанием российской науки, ей приходится решать несколько иные задачи.

Характер дискуссий в последние тридцать лет обнаружил глубинное философское основание любых трактовок нации. Это основание представляет собой, по сути, основной вопрос философии применительно к обществу: что есть социальная реальность, существуют ли в реальности социальные группы и общности и, если да, каков меха- 
низм возникновения этой реальности - от объекта к субъекту или от субъекта к объекту? Философские вопросы, как известно, не имеют окончательного решения, их смысл - в постановке проблемы, в побуждении обсуждения и поиска.

В западной научной традиции дискуссии о нации во многом зависят от доминирующих социально-философских и социальноэпистемологических установок. В российской социальной науке преобладают ценностные и практико-политические ориентиры. Изучение тех или иных научных вопросов ведется не только, а возможно, и не столько ради постижения истины, сколько ради решения актуальных проблем российского общества. Ни один из этих ориентиров не имеет преимуществ, как и не является ущербным. Проблема объективности социогуманитарного знания имеет свою длительную историю обсуждения, но в любом случае добиться свободного от социальной субъектности, полной деидеологизированности социогуманитарного знания невозможно.

Для российской науки еще с советских времен характерно ее активное вовлечение в политическую жизнь. Российская социогуманитарная наука представляет, по сути, научно-экспертное сообщество: ученые участвуют в различных общественных советах, комиссиях и коллегиях, готовят экспертно-аналитические материалы. В настоящее время, по истечении почти тридцати лет после распада СССР, этнического возрождения, сепаратизма, длительного акцента в этнополитике на поддержании культурного многообразия, на первый план выходят задачи интеграции российского общества. Выстроенная вертикаль власти не опирается на устойчивый фундамент. Концепт российской нации может выступить теоретической основой такого фундамента не потому, что он безупречен в теоретическом плане, а потому что он наиболее удачный конструкт для решения проблем пространственнотерриториального и этнокультурного развития России.

\section{Литература}

Авксентьев В.А., Аксюмов Б.В. Портфель идентичностей молодежи Юга России в условиях цивилизационного выбора // Социологические исследования. 2010. № 12 (320). C. 18-27.

Андерсон Б. Воображаемые сообщества. Размышления об истоках и распространении национализма. М. : Кучково поле, 2016.

\section{References}

Avksentev, V.A., Aksiumov, B.V. (2010). Youth of the southern Russia: a set of identities under conditions of civilization choice. Sotsiologicheskiye issledovaniya, 12 (320), 18-27. (in Russian).

Anderson, B. (2016). Imagined communities. reflections on the origin and spread of nationalism. Moscow: Kuchkovo pole. (in Russian). 
Балибар Э. Национальная форма: история и идеология // Балибар Э., Валлерстайн И. Раса, нация, класс. Двусмысленные идентичности. М. : Логос, 2004.

Баньковская С.П. Воображаемые сообщества как социологический феномен // Андерсон Б. Воображаемые сообщества. Размышления об истоках и распространении национализма. М. : Кучково поле, 2016.

Бергер П., Лукман Т. Социальное конструирование реальности. Трактат по социологии знания. М. : Медиум, 1995.

Бройи Дж. Подходы к исследованию национализма // Нации и национализм. М. : Праксис, 2002.

Бромлей Ю.В. Очерки теории этноса. М. : Наука, 1983.

Брубейкер Р. Этничность без групп. М. : Изд. дом Высшей школы экономики, 2012.

Вердери К. Куда идут «нация» и «национализм»? // Нации и национализм. М. : Праксис, 2002.

Гаджиев К.С. Российская Федерация: национальное государство или государство народов? // Полис. Политические исследования. 2018. № 3. С. 130-146.

Геллнер Э. Нации и национализм. М. : Прогресс, 1991.

Дробижева Л.М., Рыжова С.В. Гражданская и этническая идентичность и образ желаемого государства в России // Полис. Политические исследования. 2015. № 5. С. 9-24.

Калхун К. Национализм. М. : Территория будущего, 2006.

Клименко Е.В. Интеграция и различия. О гражданской нации в России // Полис. Политические исследования. 2015. № 6. С. 131-143.

Лубский А.В., Посухова О.Ю. Проекты нациестроительства и модели национальной интеграции в России // Власть. 2016. Т. 24, № 8. С. 39-48.

О внесении изменений в Стратегию государственной национальной политики Российской Федерации на период до 2025 года, утвержденную Указом Президента Российской Федерации от 19 декабря 2012 г. № 1666 : указ Президента РФ от 6 декабря 2018 г. № 703. Режим доступа: https:// www. garant.ru/products/ipo/prime/doc/72020010/.
Balibar, E. (2004). National form: history and ideology. Balibar E., Wallerstein I. Race, nation, class. Ambiguous identities. Moscow: Logos. (in Russian).

Bankovskaya, S.P. (2016). Imagined communities as a sociological phenomenon. In Anderson B. Imagined Communities. Reflections on the Origin and Spread of Nationalism. Moscow: Kuchkovo pole. (in Russian).

Berger, P.L., Luckmann, T. (1995). The Social construction of reality. A Treatise on sociology of knowledge. Moscow: Medium. (in Russian).

Breuilly, J. (2002). Approaches to nationalism. Nations and Nationalism. Moscow: Praksis. (in Russian).

Bromley, Yu.V. (1983). Essays on the theory of ethnos. Moscow: Nauka. (in Russian).

Brubaker, R. (2012). Ethnicity without groups. Moscow: Izd. dom Vysshey shkoly ekonomiki. (in Russian).

Verdery, K. (2002). Where do "Nation" and "Nationalism" go? Nations and Nationalism. Moscow: Praksis. (in Russian).

Gadzhiev, K.S. (2018). Russian Federation: national state or a state of nations? Polis. Politicheskiye issledovaniya, 3, 130-146. (in Russian).

Gellner, E. (1991). Nations and Nationalism. Moscow: Progress. (in Russian).

Drobizheva L.M., Ryzhova S.V. (2015). Civic and ethnic identity and perception of the preferable state in Russia. Polis. Politicheskiye issledovaniya, 5, 9-24. (in Russian).

Calhoun, C. (2006). Nationalism. Moscow: Territoriya budushchego. (in Russian).

Klimenko, E.V. (2015). Integration of the diversity. Formation of the civic nation in Russia. Polis. Politicheskiye issledovaniya, 6, 131-143. (in Russian). Lubsky, A.V., Posukhova, O.Yu. (2016). Nation-building projects and models of national integration in Russia. Vlast', 24, 8, 39-48. (in Russian).

Presidential Executive Order "On Amending the State Ethnic Policy Strategy of the Russian Federation until 2025 approved by Presidential Executive Order No. 1666 of December 19, 2012". Available at: https://www.garant.ru/ products/ipo/prime/doc/72020010/. (in Russian). 
Паин Э.А., Федюнин С.Ю. Нация и демократия: перспективы управления культурным разнообразием. М. : Мысль, 2017.

Семененко И.С. Нация, национализм, национальная идентичность: новые ракурсы научного дискурса // Мировая экономика и международные отношения. 2015. Т. 59, № 11. С. 91-102.

Смит Э.Д. Национализм и модернизм: критический обзор современных теорий наций и национализма. М. : Праксис, 2004.

Соколовский C.B. Онтологики национального: культурная сложность национальных сообществ и проблемы ее категоризации // Культурная сложность современных наций. М. : Политическая энциклопедия, 2016.

Сталин И.В. Марксизм и национально-колониальный вопрос : сб. избр. речей и ст. М. : Партиздат ЦК ВКП(б), 1934.

Тишков В.А. Усложняющее разнообразие: как его понимать и упорядочить // Культурная сложность современных наций. М.: Политическая энциклопедия, 2016.

Хобсбаум Э. Нации и национализм после 1780 г. СПб. : Алетейя, 1998.

Coakley J. 'Primordialism' in nationalism studies: theory or ideology? // Nations and Nationalism. 2018. Vol. 24, iss. 2. P. 327-347.

Kolstø $P$. Is imperialist nationalism an oxymoron? // Nations and Nationalism. 2018. Vol. 25, iss. 1. P. 18-44.

Nation // Wikipedia. The Free Encyclopedia. Режим доступа: https:// en.wikipedia.org/ wiki/Nation.

Seton-Watson $H$. Nations and States. An Enquiry into the Origins of Nations and the Politics of Nationalism. Boulder, Colo.: Westview Press, 1977.

\section{Поступила в редакцию}

Pain, E.A., Fedyunin, S.Yu. (2017). Nation and democracy: perspectives for managing cultural diversity. Moscow: Mysl'. (in Russian).

Semenenko, I.S. (2015). Nations, nationalism, national identity: new dimensions in academic discourse. Mirovaya ekonomika i mezhdunarodnye otnosheniya, 59, 11, 91-102. (in Russian).

Smith, A.D. (2004). Nationalism and modernism. A critical survey of recent theories of nations and nationalism. Moscow: Praksis. (in Russian).

Sokolovskiy, S.V. (2016). The ontologics of the national: the cultural complexity of national communities and the problems of its categorization. Cultural complexity of modern nations. Moscow: Politicheskaya entsiklopediya. (in Russian).

Stalin, I.V. (1934). Marxism and the national and colonial question. Collection of selected speeches and articles. Moscow: Partizdat TsK $\mathrm{VKP}(\mathrm{b})$. (in Russian).

Tishkov, V.A. (2016). Complicating diversity: how to understand and organize it. Cultural complexity of modern nations. Moscow: Politicheskaya entsiklopediya. (in Russian).

Hobsbawm, E. (1998). Nations and nationalism since 1780. Saint Petersburg: Aleteyya. (in Russian).

Coakley, J. (2018). 'Primordialism' in nationalism studies: theory or ideology? Nations and Nationalism, 24, 2, 327-347.

Kolstø, P. (2018). Is imperialist nationalism an oxymoron? Nations and Nationalism, 25, $1,18-44$.

Nation. Wikipedia. The Free Encyclopedia. Available at: https:// en.wikipedia.org/wiki/ Nation.

Seton-Watson, H. (1977). Nations and States. An Enquiry into the Origins of Nations and the Politics of Nationalism. Boulder, Colo.: Westview Press. 